\title{
Changes on soil structural stability after in natura and composted chicken manure application
}

\author{
Thadeu Rodrigues de Melo $^{1}$ (D $\cdot$ Alex Figueiredo ${ }^{1} \cdot$ Wesley Machado $^{1} \cdot$ João Tavares Filho ${ }^{1}$
}

Received: 21 March 2018 / Accepted: 19 February 2019 / Published online: 27 February 2019

(c) The Author(s) 2019

\begin{abstract}
Purpose Many studies evaluate the effect of successive applications of chicken manure on soil attributes. In Brazil, the commercialization of this waste is common, implying on its sporadic use instead of many applications at the same area. The short-term effects of a single application of chicken manure and the role of its composting on soil structural stability are not fully understood. This study investigated application of in natura (uncomposted) and composted chicken manure on the structural stability of a Rhodic Ferralsol after a short period following single application.

Methods The experiment was performed in a Rhodic Ferralsol in Londrina, Paraná. Brazil. We applied in natura and composted chicken manure at doses of 4.5, 9.0, 13.5, and $18.0 \mathrm{Mg} \mathrm{ha}^{-1}$ plus a control without application. Soil samples were collected after 185 days at the $0.0-20.0 \mathrm{~cm}$ layer for laboratorial analysis.

Results The composting of chicken manure did not affect soil structural stability. Chicken manure did not alter water-dispersible clay $(\bar{x}=21.7 \%)$, but increased the mean weight diameter of water-stable aggregates (MWD $=5.43+0.068 \times$ dose) through the agglomeration of aggregates with $0.5-4 \mathrm{~mm}$ into $8-19 \mathrm{~mm}$.

Conclusion Even after a short period of 185 days, the application of chicken manure increases the structural stability of Rhodic Ferralsols and its composting, in the way performed by many farmers, is not associated with the improvement of soil structural stability in short-term. However, other advantages arise from the composting of the manure and need to be considered prior its use.
\end{abstract}

Keywords Aggregates $\cdot$ Soil management $\cdot$ Soil physical quality $\cdot$ Organic wastes $\cdot$ Water-dispersible clay

\section{Introduction}

Structural stability is essential for the maintenance of soil quality, productive capacity, and environmental services. It is known that stable macroaggregates are directly related to the quality and persistence of soil structure (Bronick and Lal 2005; Tavares Filho et al. 2014), which can be affected by its management, such as the application of animal manures (Barbosa et al. 2015; Costa et al. 2009).

Brazil is the biggest exporter and the second biggest producer of chicken meat in the world and Paraná is the major producer state, accounting for $33 \%$ of national slaughter (ABPA 2017). With increases in chicken meat production

Thadeu Rodrigues de Melo

thadeurodrigues@hotmail.com

1 Department of Agronomy, State University of Londrina, Celso Garcia Cid Highway, s/n, Zip Code 10011, Londrina, PR CEP 86057-970, Brazil in recent decades, the generation of chicken manure has intensified, as has the need to find an adequate destination for this waste.

The major use of chicken manure is as organic fertilizer that can reduce costs to the farmers. The composting of chicken manure is recommended due to the increment of nutrients availability and the elimination of pathogens (Orrico Júnior et al. 2010), although this process is rarely done in commercial contexts. When performed, the composting is carried out in windrows, kept exposed to environmental conditions, with few or no turning of the pile.

In Brazil, chicken manure trade is well structured, and so chicken meat producers does not apply it several times at the same area. Instead, it is more common that farmers eventually buy chicken manure to use as organic fertilizer. There are several studies in the literature evaluating the effect of successive manure applications on soil attributes (Barbosa et al. 2015; Zhang et al. 2016), but few of them consider short-term effects after a single application (Costa 
et al. 2009). The role of chicken manure composting on soil structural stability after a single application is not fully understood.

Our hypothesis is that chicken manure can change soil structural stability even after a short period from its application and that the resulting changes depend on its composting. Here we tested if the application of in natura and composted chicken manure can improve the structural stability of a Rhodic Ferralsol after a short period from the application.

\section{Materials and methods}

\section{Experimental area and design}

The experiment was carried out at the State University of Londrina (latitude $23^{\circ} 23^{\prime} \mathrm{S}$, longitude $51^{\circ} 11^{\prime} \mathrm{W}$, altitude $566 \mathrm{~m}$ ) in Londrina, Paraná, Brazil (Fig. 1). According to Köppen's classification, the climate is Cfa-humid subtropical. The soil of the experimental area is classified as a Rhodic Ferralsol (IUSS Working Group WRB 2015) and its chemical and physical attributes are shown in Table 1. It was originated from basalt weathering and has a predominance of kaolinite and considerable presence of iron and aluminum sesquioxides in the clay fraction (Costa et al. 2004; Fig. 2).

The experiment was installed using a randomized block design with a factorial scheme plus an additional factor $(2 \times 4+1)$ and four replications. Chicken manure, in natura and composted, was applied at four doses $(4.5,9.0,13.5$, and

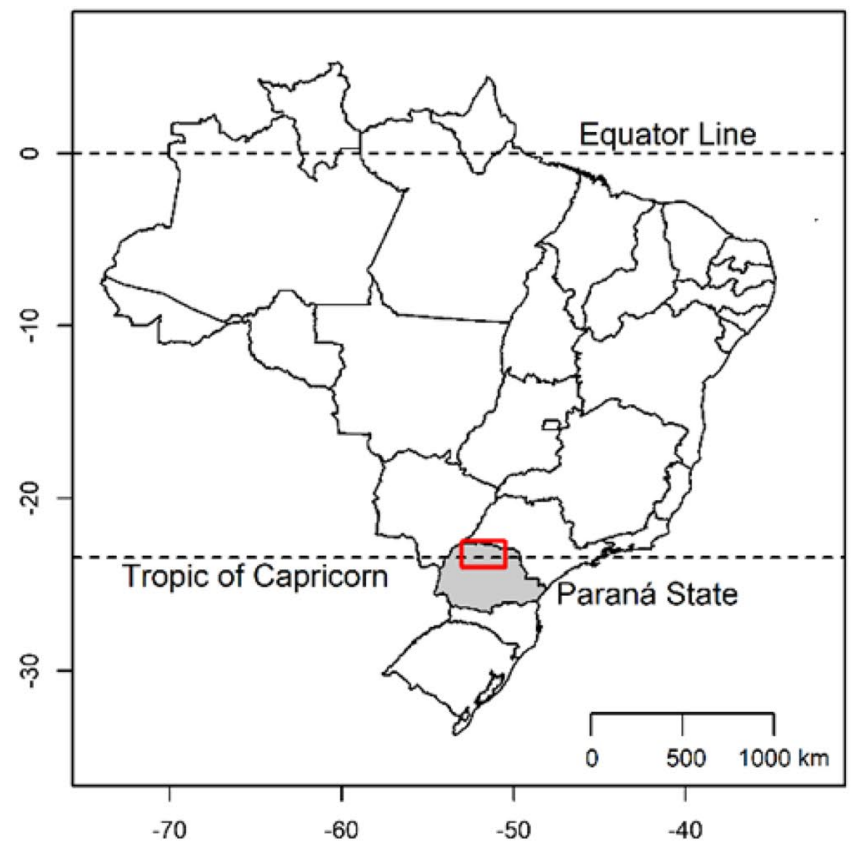

Fig. 1 Location of the experimental station in Londrina, Paraná, Brazil
Table 1 Physico-chemical characterization of the Ferralsol evaluated in the experiment

\begin{tabular}{lll}
\hline Attribute & Unit & Value \\
\hline Clay & $\mathrm{g} \mathrm{kg}^{-1}$ & 619 \\
Silt & $\mathrm{g} \mathrm{kg}^{-1}$ & 180 \\
Sand & $\mathrm{g} \mathrm{kg}^{-1}$ & 201 \\
$\mathrm{C}$ & $\mathrm{g} \mathrm{kg}^{-1}$ & 16.13 \\
$\mathrm{Ca}^{2+}$ & $\mathrm{cmol}_{\mathrm{c}} \mathrm{kg}^{-1}$ & 9.20 \\
$\mathrm{Mg}^{2+}$ & $\mathrm{cmol}_{\mathrm{c}} \mathrm{kg}^{-1}$ & 2.35 \\
$\mathrm{~K}^{+}$ & $\mathrm{cmol}_{\mathrm{c}} \mathrm{kg}^{-1}$ & 0.20 \\
$\mathrm{Na}^{+}$ & $\mathrm{cmol}_{\mathrm{c}} \mathrm{kg}^{-1}$ & 0.00 \\
$\mathrm{Al}^{3+}$ & $\mathrm{cmol}_{\mathrm{c}} \mathrm{kg}^{-1}$ & 0.00 \\
$\mathrm{pH}_{\mathrm{H}_{2} \mathrm{O}}$ & $\left.-\log _{\mathrm{mol}}^{-1}\right]$ & 6.17 \\
$\Delta \mathrm{pH}$ & - & -0.67 \\
\hline
\end{tabular}

Analyses performed in samples sieved at $2 \mathrm{~mm}$. Granulometry determined after dispersion with $\mathrm{NaOH}\left(0.1 \mathrm{~mol} \mathrm{~L}^{-1}\right)$ during $16 \mathrm{H}$ at 200 RPM; C: carbon determined after oxidation with $\mathrm{K}_{2} \mathrm{Cr}_{2} \mathrm{O}_{7}$; exchangeable cations extracted with $\mathrm{KCl} 1 \mathrm{~mol} \mathrm{~L}^{-1}\left(\mathrm{Ca}^{2+}, \mathrm{Mg}^{2+}\right.$ and $\left.\mathrm{Al}^{3+}\right)$ and with Mehclich-1 $\left(\mathrm{K}^{+}\right.$and $\left.\mathrm{Na}^{+}\right) ; \mathrm{pH}_{\mathrm{H}_{2} \mathrm{O}}$ and $\mathrm{pH}_{\mathrm{KCl}}$ determined in a 1:2.5 soil/solution ( $m: v$ ) ratio; $\Delta \mathrm{pH}=\mathrm{pH}_{\mathrm{KCl}}-\mathrm{pH}_{\mathrm{H}_{2} \mathrm{O}}$

18.0 $\mathrm{Mg}$ of dry matter $\mathrm{ha}^{-1}$ ); the control had neither waste nor mineral fertilizers applied.

The chicken manure was collected from a commercial aviary located in Londrina, Paraná, which houses 12 chickens $\mathrm{m}^{-2}$, 1 week after the removal of the fifth flock. Part of the collected chicken manure was air-dried and protected from rain and air moisture (in natura chicken manure), while the remaining was composted until thermal

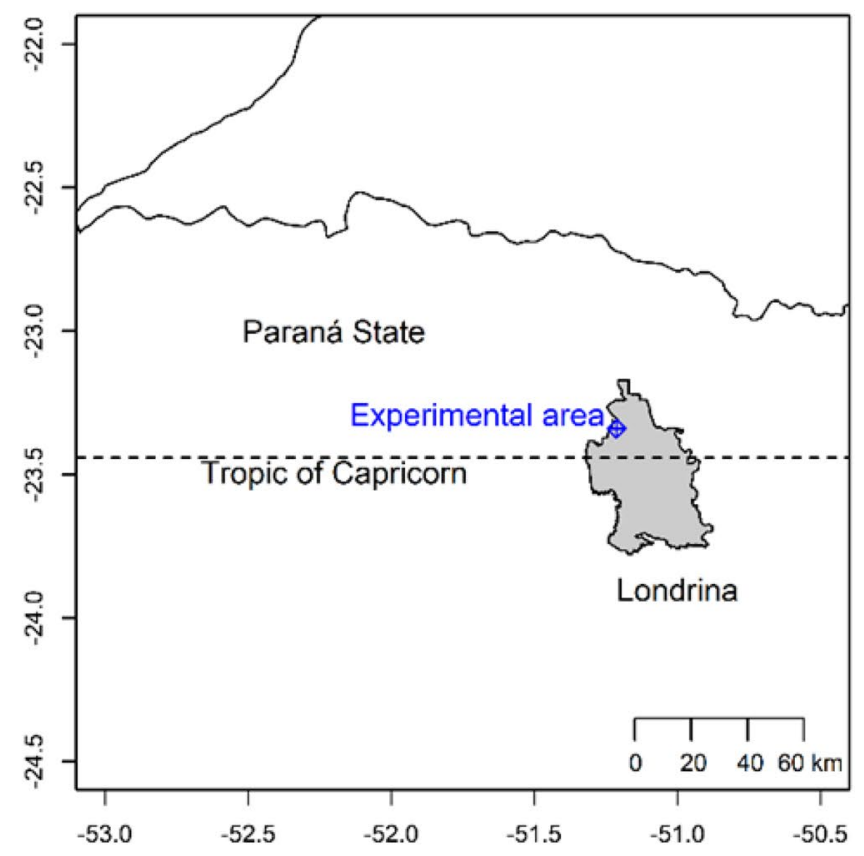




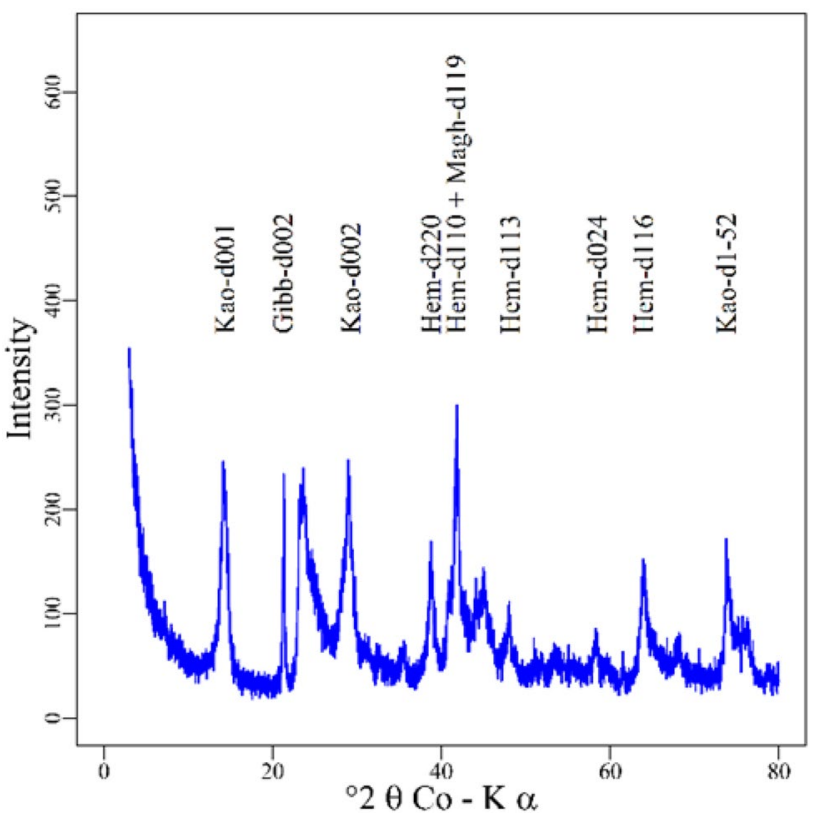

Fig. 2 X-ray diffractogram of the clay fraction from the Rhodic Ferralsol under study

Table 2 Characterization of the chicken manures used in the experiment

\begin{tabular}{llll}
\hline Attribute & Unit & In natura & Composted \\
\hline $\mathrm{pH}_{\mathrm{H}_{2} \mathrm{O}}$ & - & 6.8 & 7.5 \\
$\mathrm{C}$ & $\mathrm{g} \mathrm{kg}^{-1}$ & 380 & 405 \\
$\mathrm{~N}$ & $\mathrm{~g} \mathrm{~kg}^{-1}$ & 27.0 & 24.7 \\
$\mathrm{Ca}$ & $\mathrm{g} \mathrm{kg}^{-1}$ & 45.6 & 42.3 \\
$\mathrm{Mg}$ & $\mathrm{g} \mathrm{kg}^{-1}$ & 5.6 & 3.4 \\
$\mathrm{~K}$ & $\mathrm{~g} \mathrm{~kg}^{-1}$ & 29.1 & 35.1 \\
$\mathrm{~S}$ & $\mathrm{~g} \mathrm{~kg}^{-1}$ & 7.5 & 6.7 \\
$\mathrm{Zn}$ & $\mathrm{mg} \mathrm{kg}^{-1}$ & 280 & 190 \\
$\mathrm{Cu}$ & $\mathrm{mg} \mathrm{kg}^{-1}$ & 390 & 295 \\
$\mathrm{Fe}$ & $\mathrm{mg} \mathrm{kg}^{-1}$ & 2885 & 2689 \\
\hline
\end{tabular}

$\mathrm{pH}_{\mathrm{H}_{2} \mathrm{O}}$ determined at 1:10 (m:v) proportion; C determined after oxidation with $\mathrm{K}_{2} \mathrm{Cr}_{2} \mathrm{O}_{7}$; $\mathrm{N}$ determined after sulfuric digestion; $\mathrm{Ca}, \mathrm{Mg}, \mathrm{K}$, $\mathrm{Na}, \mathrm{S}, \mathrm{Zn} \mathrm{Cu}$ and $\mathrm{Fe}$ determined after nitropercloric digestion

stabilization (composted chicken manure) (Table 2). The composting process consisted of visual and tactile monitoring of moisture every 3 days, with subsequent wetting and plowing of the pile.

After the black oat (Avena strigosa Schreb.), used as green manure in the winter, the chicken manure was manually applied on the soil surface. Soybean was cultivated and harvested in the area before soil sampling. Soil samples were collected at $0.0-20.0 \mathrm{~cm}$ for chemical and physi$\mathrm{cal}$ analyses. The period between chicken manure application and soil sampling was 185 days (Fig. 3).

\section{Laboratorial analyses}

The stability of soil aggregates $(<19 \mathrm{~mm})$ in water was evaluated according to Castro Filho et al. (1998), using sieves with $8,4,2,1,0.5$, and $0.25 \mathrm{~mm}$ mesh, in triplicate. The mean weighted diameter was calculated, after the correction of samples according to their dry mass $\left(105^{\circ} \mathrm{C}\right)$, as:

$\mathrm{MWD}=\sum D_{i} \times w_{i}$

Where: $D_{i}$-arithmetic mean of superior and inferior sieve mesh in relation to each aggregate size class; and $w_{i}-$ proportion of each class (mass) in relation to the sample.

Samples were sieved $(2 \mathrm{~mm})$ for chemical, granulometric, and water-dispersible clay (WDC) analysis. The total organic carbon (C) was quantified by titration with $\mathrm{FeSO}_{4}$ after oxidation with $\mathrm{K}_{2} \mathrm{Cr}_{2} \mathrm{O}_{7}$ in sulfuric medium. The $\mathrm{pH}_{\mathrm{H}_{2} \mathrm{O}}$ was measured in a 1:2.5 soil/water ratio $(m: v) . \mathrm{Ca}^{2+}, \mathrm{Mg}^{2+}$, and $\mathrm{Al}^{3+}$ were extracted with $\mathrm{KCl}\left(1 \mathrm{~mol} \mathrm{~L}^{-1}\right)$ and determined by titration with EDTA- $\mathrm{Na}_{2}\left(\mathrm{Ca}^{2+}\right.$ and $\left.\mathrm{Mg}^{2+}\right)$ and $\mathrm{NaOH}$ $\left(\mathrm{Al}^{3+}\right) \cdot \mathrm{K}^{+}$and $\mathrm{Na}^{+}$were extracted with MEHLICH-1 and quantified by flame photometry.

For granulometric analysis, $100 \mathrm{~mL}$ of $\mathrm{NaOH}(0.1 \mathrm{~mol}$ $\mathrm{L}^{-1}$ ) was added in plastic bottles containing $20 \mathrm{~g}$ of soil. The suspension was shaken for $16 \mathrm{~h}$ at $200 \mathrm{RPM}$. The WDC was determined after shaking $20 \mathrm{~g}$ of soil and $100 \mathrm{~mL}$ of distilled water for $1 \mathrm{~h}$ at 200 RPM. Stoke's law was used to calculate the sedimentation time of the clay fraction $\left(\varnothing<2 \times 10^{-6} \mathrm{~m}\right)$.

\section{Statistical methods}

ANOVA was performed using Box-Cox transformation when the assumptions of homoscedasticity or normality, evaluated by Bartlett's and Shapiro-Wilk's tests, respectively, were not obeyed. Regression models were used to express the relationship between the chicken manure doses and the response variables.

\section{Results and discussion}

Chicken manure increased the structural stability of the studied Ferralsol regardless its composting. The composting process did not substantially alter the chemical attributes of the manure (Table 2), corroborating Orrico Júnior et al. (2010), which used the same composting method of the present study. However, due to the visual changes of the manure, we believe that the changes in the organic compounds were more qualitative than quantitative, which can be associated with the transformation of aliphatic molecules into aromatic (Merlin et al. 2014).

During the period of the experiment, moderate temperatures and high pluviosity were observed (Fig. 3) and must 


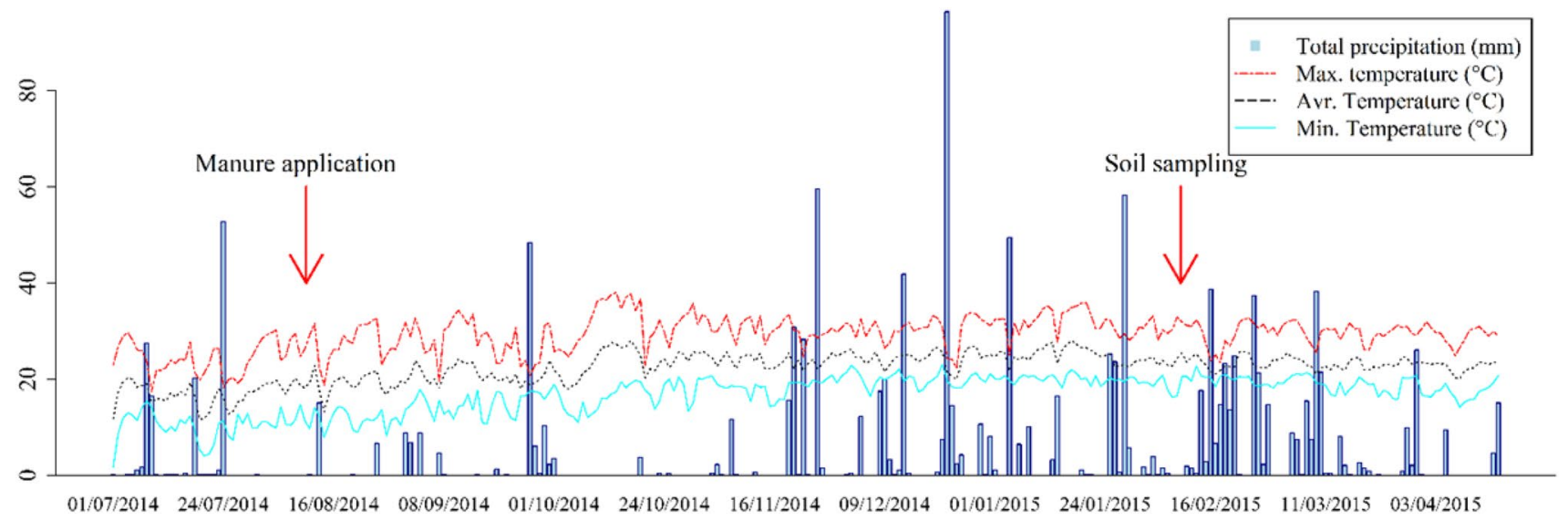

Fig. 3 Daily total precipitation and average, maximum and minimum temperature during the period of the experiment

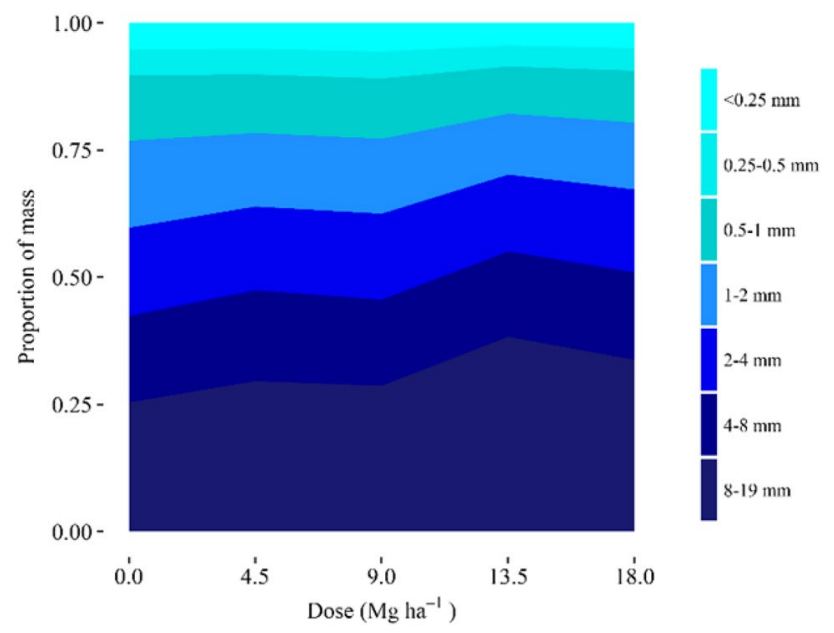

Fig. 4 Proportion of water-stable aggregate size classes as a function of chicken manure doses

have allowed the decomposition of most of the manure. Studies under comparable conditions and time suggest $60 \%$ of decomposition (Pitta et al. 2012). Considering that the chicken manure is mainly composed of chicken feces and wood dust (Rogeri et al. 2016), most of this decomposition must be associated with feacal degradation once it has low $\mathrm{C}: \mathrm{N}$ ratio and is easily degradable.

The statistically significant increment caused by chicken manure application occurred regardless of its composting and mainly through the agglomeration of $0.5-4 \mathrm{~mm}$ into 8-19 mm aggregates (Figs. 4, 5). The MWD values of our study are within the expected range, as observed by other authors studying soils weathered from basalt in Paraná (Barbosa et al. 2015; Gonçalves et al. 2013). These soils have a good resistance to hydric erosion (Reichert et al. 2009) and the increment in MWD caused by chicken manure can intensify this characteristic, once some studies suggest that
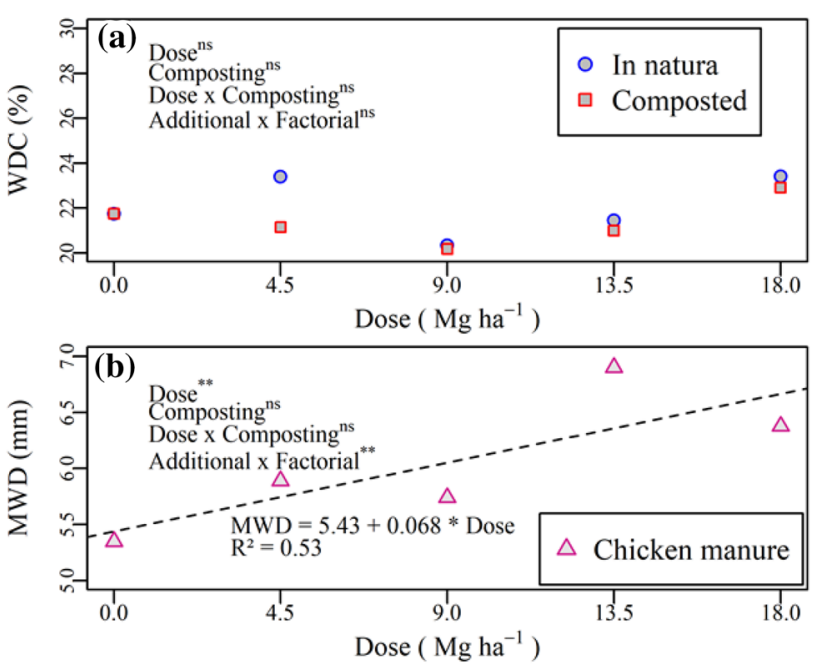

Fig. 5 Water-dispersible clay (WDC) and mean weight diameter (MWD) as a function of chicken manure doses

aggregates bigger than $2 \mathrm{~mm}$ are less susceptible to be transported by water (Calegari et al. 2006; Xiao et al. 2017).

These changes corroborate those found by Veiga et al. (2009), who reported an increase in the stability of the aggregates of a Hapludox in southern Brazil after the application of chicken manure for 9 years. In our study, the supply of organic molecules from the manure favored the stabilization of larger aggregates, despite no statistical change could be observed on C (Fig. 6a). This could have happened because of the reduction of the wettability of the minerals (Chenu et al. 2000) and the formation of bonds between particles (Abiven et al. 2007). Additionally, the stimulus to soil biota activity, through the application of the chicken manure, can favor the stabilization of larger aggregates by the cementation of the smaller ones because 

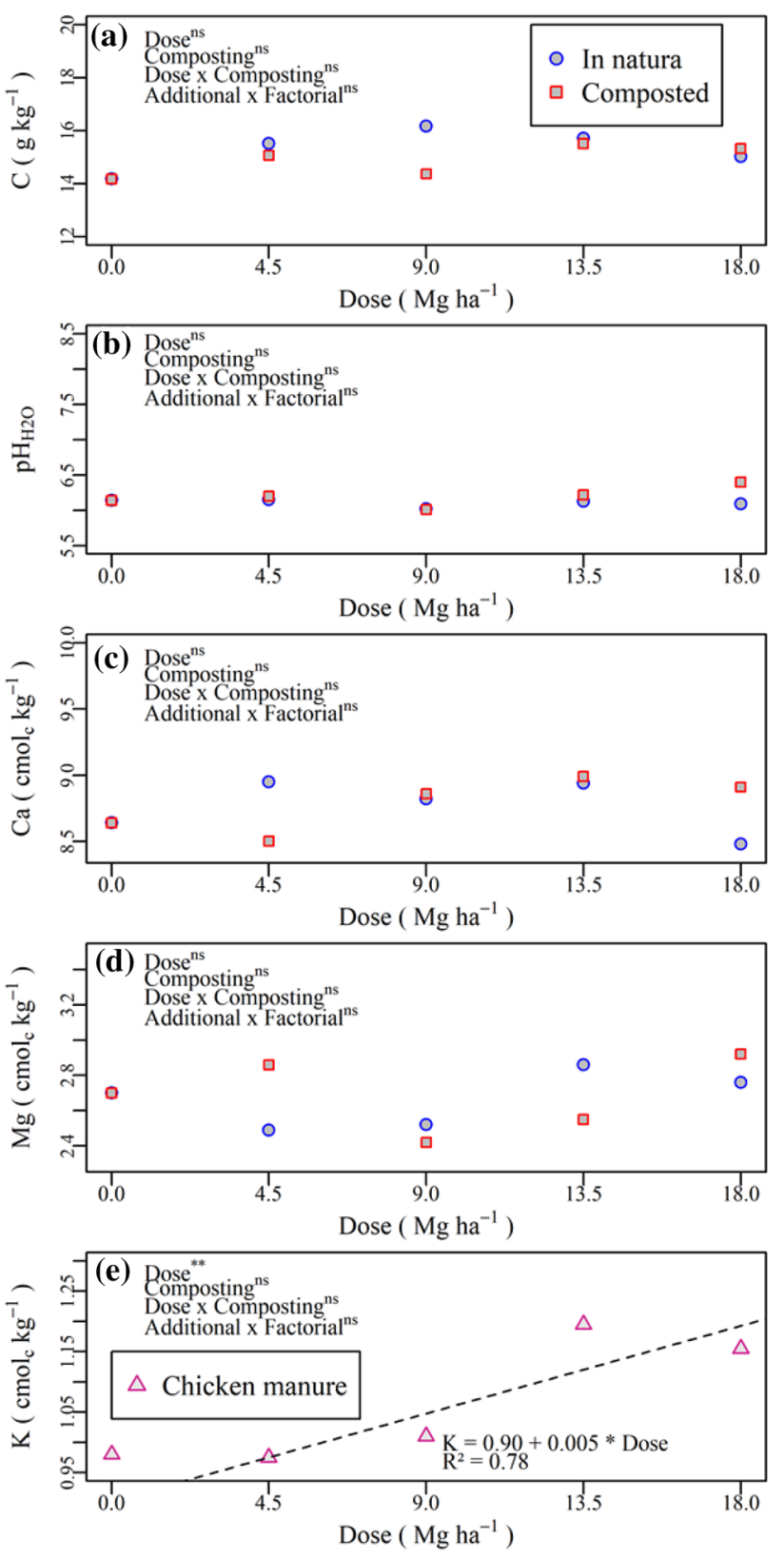

Fig. 6 Chemical attributes of the Rhodic Ferralsol as a function of chicken manure doses

of the production of microbial exudates and fungal hyphae (Cardoso et al. 2013).

The absence of difference between the manures in the present study is probably associated with the single application on the area and the composting method adopted. Studying the effects of in natura and composted chicken manure on the physical attributes of a sandy loam Oxisol, Valadão et al. (2011) observed that composted chicken manure increased the MWD in comparison to the area under in natura chicken manure after 8 years of continuous application. However, these authors used an automatic agitator that allowed the stabilization of the composting process in just 18 days. The rapid stabilization of the manure indicates a higher proportion of stable molecules after composting and explains the observed difference between the manures.

MWD was more responsive to chicken manure application than WDC (Fig. 5). Melo et al. (2015) also did not find differences in WDC after 90 days from the chicken manure application in an experiment in pots using the same soil as in the present study. Costa et al. (2009), however, showed a reduction in WDC after 60 days of the chicken manure application in a coarser Ferralsol from Minas Gerais, Brazil, revealing the variability of response due to the characteristics of each soil.

The Rhodic Ferralsols have a high content of kaolinite and metallic sesquioxides, mainly of iron in the clay fraction (Costa et al. 2004, Fig. 2). These minerals have sites of positive charges in the common soil conditions, which favors the electrostatic attraction and the formation of organic bonds between clays (Igwe et al. 2009; Tombácz and Szekeres 2006). The colloidal protection of organic matter is intense in these soils, coating the clay particles with organic molecules, which reduces their isoelectric point and make their dispersion less responsive to the addition of organic wastes.

The $\mathrm{pH}$ increment can intensify the charges unbalance at the surface of the particles, increasing their dispersion (Lee et al. 2012; Nguyen et al. 2013). In addition, changing the proportion of the exchangeable cations can expand the electric double layer and so the dispersion of the clay fraction (Mahanta et al. 2014). However, the treatments did not cause changes on these variables, except for K, (Fig. 6), explaining why the chicken manure addition did not influence WDC. Despite the changes on $\mathrm{K}^{+}$ content, it probably was not enough to increase the dispersion of the clay fraction. This affirmation corroborates Melo et al. (2018), testing doses of sugarcane vinasse in a Cambisol from Brazil, who observed that the increment of $\mathrm{K}^{+}$up to almost $5 \%$ of the cation exchange capacity was not enough to increase the water-dispersible clay content.

\section{Conclusion}

Even after a short period of 185 days, the application of chicken manure increases the structural stability of Rhodic Ferralsols and its composting, in the way performed by many farmers, is not associated with the improvement of soil structural stability in short-term. However, other advantages arise from the composting of the manure and need to be considered prior its use.

Acknowledgements We acknowledge the National Council for the Improvement of Higher Education-CAPES (Grant no. Finance Code 001) and the National Council for Scientific and Technological Development-CNPq (Grant no. 140987/2016-9 - PhD scholarship) for granting the productivity and the $\mathrm{PhD}$ scholarships to the authors. 


\section{Compliance with ethical standards}

Conflict of interest The authors declare that there are no conflicts of interest associated with this study.

Open Access This article is distributed under the terms of the Creative Commons Attribution 4.0 International License (http://creativeco mmons.org/licenses/by/4.0/), which permits unrestricted use, distribution, and reproduction in any medium, provided you give appropriate credit to the original author(s) and the source, provide a link to the Creative Commons license, and indicate if changes were made.

\section{References}

Abiven S, Menasseri S, Angers DA, Leterme P (2007) Dynamics of aggregate stability and biological binding agents during decomposition of organic materials. Eur J Soil Sci 58:239-247. https://doi. org/10.1111/j.1365-2389.2006.00833.x

Barbosa GMC, Oliveira JF, Miyazawa M, Ruiz DB, Filho Tavares (2015) Aggregation and clay dispersion of an Oxisol treated with swine and poultry manures. Soil Till Res 146:279-285. https://doi. org/10.1016/j.still.2014.09.022

Brazilian Association of Animal Protein-ABPA. Annual report 2017. http://abpa-br.com.br/storage/files/final_abpa_relatorio_anual _2017_ingles_web.pdf. Accessed 17 Sept 2017

Bronick CJ, Lal R (2005) Soil structure and management: a review. Geoderma 124:3-22. https://doi.org/10.1016/j.geoderma.2004.03.0

Calegari A, Castro Filho C, Tavares Filho J, Ralisch R, Guimarães MF (2006) Soil particle aggregation improvement through notillage system. Semina: Cienc. Agrar 27:147-158. https://doi. org/10.5433/1679-0359.2006v27n2p147

Cardoso EJBN, Vasconcellos RLF, Bini D, Miyauchi MYH, dos Santos CA, Alves PRL, de Paula AM, Nakatani AS, Pereira JM, Nogueira MA (2013) Soil health: looking for suitable indicators. What should be considered to assess the effects of use and management on soil health? Sci Agric 70:274-289. https://doi.org/10.1590/S0103-90162 013000400009

Castro Filho C, Muzilli O, Podanoschi AL (1998) Estabilidade dos agregados e sua relação com o teor de carbono orgânico num Latossolo Roxo distrófico, em função de sistemas de plantio, rotações de culturas e métodos de preparo das amostras. Rev Bras Cienc Solo 22:527-538. https://doi.org/10.1590/S0100-06831998000300019

Chenu C, Bissonnais Y, Arrouays D (2000) Organic matter influence on clay wettability and soil aggregate stability. Soil Sci Soc Am J 64:1479-1486. https://doi.org/10.2136/sssaj2000.6441479x

Costa ACS, Bigham JM, Tormena CA, Pintro JC (2004) Clay mineralogy and cation exchange capacity of Brazilian soils from water contents determined by thermal analysis. Thermochim Acta 413:73-79. https ://doi.org/10.1016/j.tca.2003.10.009

Costa AM, Borges EN, Silva AA, Nolla A, Guimarães EC (2009) Potencial de recuperação física de um Latossolo Vermelho, sob pastagem degradada, influenciado pela aplicação de cama de frango. Cienc Agrotec 33:1991-1998. https://doi.org/10.1590/S1413-7054200900 0700050

Gonçalves MA, Tavares Filho J, Vendrame PRS, Telles TS (2013) Toposequences of soils developed on basaltic rocks: physicochemical attributes. Rev Cienc Agrar 56:359-370. https://doi.org/10.4322/ rca.2013.054

Igwe CA, Zarei M, Stahr K (2009) Colloidal stability in some tropical soils of southeastern Nigeria as affected by iron and aluminium oxides. Catena 77:232-237. https://doi.org/10.1016/j.caten a.2009.01.003

IUSS Working Group WRB. World reference base for soil resources 2014, update 2015. International soil classification system for naming soils and creating legends for soil maps. World Soil. No. 106. FAO, Rome

Lee BJ, Schlautman MA, Toorman E, Fettweis M (2012) Competition between kaolinite flocculation and stabilization in divalent cation solutions dosed with anionic polyacrylamides. Water Res 46:56965706. https://doi.org/10.1016/j.watres.2012.07.056

Mahanta KK, Mishra GC, Kansal ML (2014) Estimation of the electric double layer thickness in the presence of two types of ions in soil water. Appl Clay Sci 87:212-218. https://doi.org/10.1016/j. clay.2013.11.007

Melo TR, Ferreira RRM, Navroski D, Feltran CTM, Tavares Filho J (2018) Physico-chemical attributes of a Cambisol under pasture managed with annual burns after sugarcane vinasse application. Int J Recyc Org Waste Agric 7:75-81. https://doi.org/10.1007/s40093-018-0193-y

Melo TR, Machado W, Tavares Filho J (2015) Correlation of cationic indices with clay dispersion degree of two soils from Brazil fertilized with chicken manure. Int J Plant Soil Sci 4:338-351. https://doi. org/10.9734/IJPSS/2015/12026

Merlin N, Nogueira BA, Lima VA, Santos LM (2014) Application of fourier transform infrared spectroscopy, chemical and chemometrics analyses to the characterization of agro-industrial waste. Quim Nova 37:1584-1588. https://doi.org/10.5935/0100-4042.20140259

Nguyen MN, Dultz S, Tran TTT, Bui ATK (2013) Effect of anions on dispersion of a kaolinitic soil clay: a combined study of dynamic light scattering and test tube experiments. Geoderma 209-210:209-213. https://doi.org/10.1016/j.geoderma.2013.06.024

Orrico Júnior MAP, Orrico ACA, Lucas Júnior J (2010) Compostagem dos resíduos da produção avícola: cama de frangos e carcaças de aves. Eng Agric 30:538-545. https://doi.org/10.1590/S0100-69162 010000300017

Pitta CSR, Adami PF, Pelissari A, Assmann TS, Franchin MF, Cassol LC, Sartor LR (2012) Year-round poultry litter decomposition and N, P, K and Ca release. Rev Bras Cienc Solo 36:1043-1053. https ://doi.org/10.1590/S0100-06832012000300034

Reichert JM, Norton LD, Favaretto N, Huang C, Blume E (2009) Settling Velocity, Aggregate Stability, and Interrill Erodibility of Soils Varying in Clay Mineralogy. Soil Sci Soc Am J 73:1369-1377. https:// doi.org/10.2136/sssaj2007.0067

Rogeri DA, Ernani PR, Mantovani A, Lourenço KS (2016) Composition of poultry litter in Southern Brazil. Rev Bras Cienc Solo 40:e0140697. https://doi.org/10.1590/18069657rbcs20140697

Tavares Filho J, Melo TR, Machado W, Maciel BV (2014) Structural changes and degradation of Red Latosols under different management systems for 20 years. Rev Bras Cienc Solo 38:1293-1303. https://doi.org/10.1590/S0100-06832014000400025

Tombácz E, Szekeres M (2006) Surface charge heterogeneity of kaolinite in aqueous suspension in comparison with montmorillonite. Appl Clay Sci 34:105-124. https://doi.org/10.1016/j.clay.2006.05.009

Valadão FCA, Maas KDB, Weber OLS, Valadão Júnior DD, da Silva TJ (2011) Variação nos atributos do solo em sistemas de manejo com adição de cama de frango. Rev Bras Cienc Solo 35:2073-2082. https ://doi.org/10.1590/S0100-06832011000600022

Veiga M, Reinert DJ, Reichert JM (2009) Aggregate stability as affected by short and long-term tillage systems and nutrient sources of a Hapludox in southern Brazil. Rev Bras Cienc Solo 33:767-777. https:// doi.org/10.1590/S0100-06832009000400003

Xiao S, Zhang W, Ye Y, Zhao J, Wang K (2017) Soil aggregate mediates the impacts of land uses on organic carbon, total nitrogen, and microbial activity in a Karst ecosystem. Sci Rep UK 7:41402. https ://doi.org/10.1038/srep41402

Zhang S, Yang RWX, Sun B, Li Q (2016) Soil aggregation and aggregating agents as affected by long term contrasting management of an Anthrosol. Sci Rep UK 6:39107. https://doi.org/10.1038/srep39107

Publisher's Note Springer Nature remains neutral with regard to jurisdictional claims in published maps and institutional affiliations. 